\title{
Initial Experimental Experience with a Sprayable Biodegradable Polymer Membrane (SBPM) Technology in Cotton
}

\author{
Michael V. Braunack ${ }^{1}$, Raju Adhikari ${ }^{2}{ }^{\circledR}$, George Freischmidt ${ }^{2}$, Priscilla Johnston ${ }^{2}$, \\ Philip S. Casey ${ }^{2}$, Yusong Wang ${ }^{3}$, Keith L. Bristow ${ }^{3, *}$, Lana Filipović ${ }^{4}$ (D) and \\ Vilim Filipović ${ }^{3,4, *(D)}$ \\ 1 CSIRO, Agriculture \& Food, LB 59 Narrabri, NSW 2390, Australia; Michael.Braunack@csiro.au \\ 2 CSIRO, Manufacturing, Private Bag 33, Clayton, VIC 3169, Australia; adhikari2428@gmail.com (R.A.); \\ george.freischmidt@gmail.com (G.F.); priscilla.johnston82@gmail.com (P.J.); philcasey54@gmail.com (P.S.C.) \\ 3 CSIRO, Agriculture \& Food, PMB, Aitkenvale, Townsville, QLD 4814, Australia; Yusong.Wang@csiro.au \\ 4 Department of Soil Amelioration, University of Zagreb Faculty of Agriculture, Svetošimunska 25, \\ 10000 Zagreb, Croatia; lfilipovic@agr.hr \\ * Correspondence: Keith.Bristow@csiro.au (K.L.B.); vfilipovic@agr.hr (V.F.); \\ Tel.: +61-408-468-941 (K.L.B.); +385-1-2393-711 (V.F.)
}

Received: 18 March 2020; Accepted: 16 April 2020; Published: 19 April 2020

\begin{abstract}
Preformed biodegradable and next generation sprayable biodegradable polymer membrane (SBPM) formulations, which biodegrade to non-harmful products (water, carbon dioxide and microbial biomass), have been introduced as an alternative to plastic mulch films in order to mitigate plastic pollution of the environment. In this preliminary field study on cotton (Gossypium hirsutum L.), a novel SBPM technology was compared to preformed slotted oxo-degradable plastic (ODP) mulch film and no mulch control (CON) in terms of yield, crop water productivity (CWP), and soil temperature. The first results showed higher CWP and crop yield, and increased soil water content under the SBPM cover. This study indicates that SBPM technology could perform at similar level as ODP or comparable films under field conditions and, at the same time, provide environmentally sustainable agricultural cropping practices. Additionally, the fully treated, non-replicated SBPM plot had a wetter soil profile throughout the entire crop season. This innovative technology has shown a high potential even at this early stage of development, indicating that advances in formulation and further testing can lead to significant improvements and thus increased use in crop production systems.
\end{abstract}

Keywords: preformed plastic mulch film; crop water productivity; biodegradation; crop productivity; spray-on mulch; water use efficiency

\section{Introduction}

As the world population continues to increase, the production of food and fibre will need to increase using the same (or reduced) area of agricultural land, but with less water [1]. One of the ways to increase crop productivity is to minimise water losses by soil evaporation and crop transpiration [2], which can be achieved in the field by using various mulch surface covers and/or with improved irrigation technologies. Plastic mulch films used in crop production help to control pests, increase soil and air temperature, reduce soil evaporation, minimize soil erosion, and prevent soil particles attaching to fruits or vegetables [3]. However, a major and continuing problem with the use of plastic mulch films is disposal and non-biodegradability issues [4]. Consequently, the expanding use of plastics has led to environmental pollution, which will have long-term consequences on soil quality, the environment, and possibly human health [5]. The newer oxo-degradable mulch films 
reduce the amount of plastic mulch currently being disposed in landfills, but are still essentially non-biodegradable [6]. The result is that they break down to smaller fragments, causing even more environmental damage [7]. Biodegradable plastics are a promising solution, but the release of microand nanoparticles from biodegradable plastic upon degradation requires long term field trials in order to confirm that either complete biodegradation occurs, or that no long-term harm to the environment is caused [8].

Recently, a biodegradable spray-on mulch based on sodium alginate was developed as a potential alternative to the thin plastic mulch films currently used in horticulture [9]. Polymeric protein-based biodegradable spray coatings were tested in greenhouse trials [10] and exhibited agronomic performances comparable to commercial low-density polyethylene mulch film, indicating a similar rate of plant growth and dry matter accumulation and a complete biodegradation $(<5 \%$ residues after 2 months). Similar sprayable polymer formulations (for small scale handheld sprayers and large-scale mechanised boom sprays) designed to biodegrade have been reported previously [11,12]. An increase in crop water productivity of $20 \%-30 \%$ for rockmelons under drip irrigation was demonstrated using a sprayable biodegradable polymer membrane (SBPM) compared to the bare soil [13]. The use of an additional viscosity modifier reduced soil wicking (polymer adsorption into the soil) by $10 \%-90 \%$ without compromising the system's sprayability or the general mechanical properties of the membrane, which were similar to those of the unmodified SBPM. Soil evaporation was reduced by more than $60 \%$ at a low SBPM application rate [14]. The beneficial effect of SBPM on the soil water regime in terms of the restriction of soil evaporation was even more pronounced when the polymer application rate increased (up to $1 \mathrm{~kg} \mathrm{~m}^{-2}$ ) [15].

Using the same SBPM formulation [15], a field study was conducted to determine whether SBPM applied to irrigated cotton would be effective in conserving soil profile water and improving crop water productivity and yield. This research was conducted to give important small-scale insights, before expanding and upscaling to full field scale research. The aim was to compare SBPM with oxo-degradable plastic (ODP) mulch film and with no mulch control (CON) in terms of the soil water content, soil temperature, cotton yield, and cotton quality.

\section{Materials and Methods}

\subsection{Experimental Field Set-Up}

Field experiments were conducted during the 2014/2015 season at the Australian Cotton Research

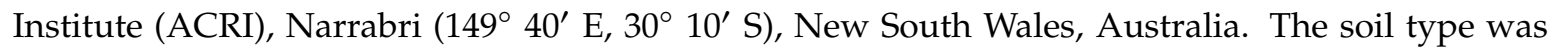
classified as a grey self-mulching Vertosol with $59 \%$ clay, $28 \%$ silt, a pH of $7.27\left(0.01 \mathrm{M} \mathrm{CaCl}_{2}\right)$ and $0.77 \%$ Organic Carbon on average [16]. Nitrogen fertiliser was applied as urea at the rate of $180 \mathrm{~kg} \mathrm{~N} \mathrm{ha}^{-1}$ prior to planting. Weeds and insects were managed as per Bollgard ${ }^{\circledR}$ II protocol and plots were irrigated according to the station's schedule when an approximate soil profile water deficit of 70-80 mm was detected. Cotton (Gossypium hirsutum L. cultivar Sicot 74 BRF, germination percentage 96\%) was sown (10 seeds per $\mathrm{m}$ of row) on 26 October 2015.

Three treatments, laid out as a completely randomised block design with three replicates, were tested: a thin slotted oxo-degradable polyethylene clear plastic (ODP) film, a new spray-on biodegradable polymer membrane (SBPM_gap) was applied on both sides of the plant row using a handheld pressure sprayer (Figure 1), and no mulch control (CON). The sprayable polymer formulation contained $20 \mathrm{wt} \%$ polymer content with $100-500 \mu \mathrm{m}$ particle size and viscosity in the range of 50-100 $\mathrm{mPa}$. The polymer formulation that showed the best combination of film formation, water barrier and mechanical properties in the previous pot trial [13] was selected for the field trial. An unsprayed area $(12 \mathrm{~cm})$ between the spray lines was left to ensure that cotton seedlings would emerge. In one additional plot, SBPM was diluted by half to $0.5 \mathrm{~L} \mathrm{~m}^{-2}$ and applied over the plant line to determine whether cotton would emerge through the polymer membrane (SBPM_full). An additional 
plot with spray-on SBPM applied over the plant line (SBPM_full) was not replicated (due to the limited amount of available SBPM) and therefore was not included in the statistical analysis.

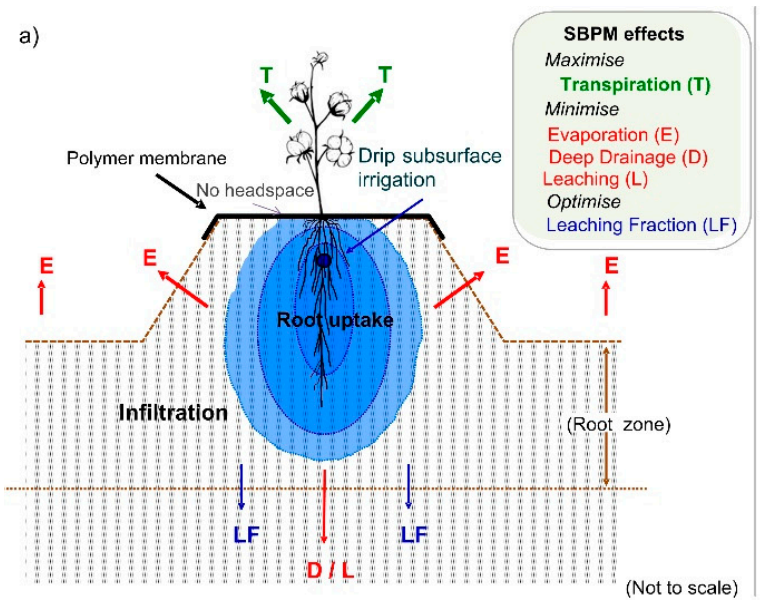

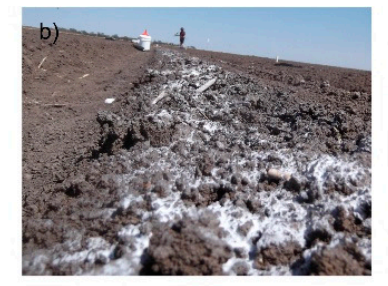
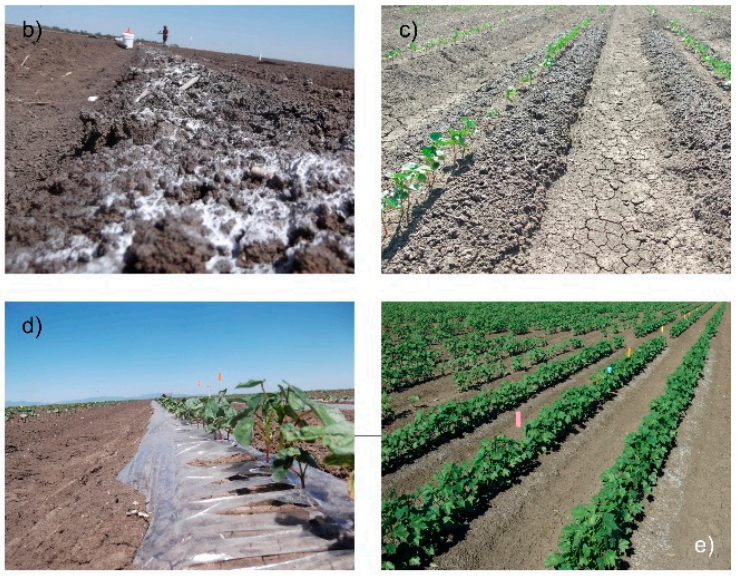

Figure 1. (a) Conceptual sketch of a sprayable biodegradable polymer membrane (SBPM)'s effect on relatively small-scale soil hydrology. (b) Soil after the application of SBPM_full spray-on, (c) SBPM_gap plot, (d) oxo-degradable plastic (ODP) slotted mulch film plot, (e) experimental layout in the field during October/November 2015 at the Australian Cotton Research Institute (ACRI), Narrabri.

\subsection{Field Sensor Installation and Crop Data Collection}

Sensors were installed prior to applying the preformed film and the spray-on polymer. The soil profile water content and seedbed soil temperature were monitored below the plant line in each plot, respectively, using multi-depth soil capacitance sensors (at 10, 20, 40, 60 and $80 \mathrm{~cm}$ soil depth, Odyssey, http://odysseydatarecording.com/), and with thermistor probes (at $10 \mathrm{~cm}$ depth, Tinytag provided by Hastings Data Loggers, www.hdl.com.au). Data logging was commenced two days after the installation to allow soil moisture to re-equilibrate. Crop water consumption (CWC, $\mathrm{mm}$ ) was determined using a simple mass balance expression: initial profile water (IPW) + irrigation (IR) + in-crop rainfall (R) final profile water $(\mathrm{FPW})$ (i.e., $\mathrm{CWC}=(\mathrm{IPW}+\mathrm{IR}+\mathrm{R})-\mathrm{FPW})$ and crop water productivity $(\mathrm{CWP})$ $\left(\mathrm{kg}\right.$ lint $\left.\mathrm{mm}^{-1} \mathrm{ha}^{-1}\right)=$ lint yield $\left(\mathrm{kg} \mathrm{ha}^{-1}\right) /(\mathrm{CWC}-100 \mathrm{~mm})$. The threshold of $100 \mathrm{~mm}$ was used to account for runoff, evaporation, and plant growth at the early growing stage, as proposed in previous studies under the same climatic conditions $[17,18]$. This approach was recommended given the local experience in New South Wales and Queensland cultivation systems, where $60 \%-80 \%$ of rainfall is lost as runoff and evaporation during the initial crop growing stages.

Crop establishment was determined by counting the number of plants when no further seedlings had emerged at 51 days after sowing (DAS), and crop height was determined by measuring the height of all plants 122 DAS, when no further increase in height was observed. Crop yield was determined by picking all cotton bolls at maturity and the fibre quality was assessed using a Hi Value Instrument (HVI - Uster Technologies and https://www.cottoninfo.com.au/fibre-quality). Field crop quality parameters (CWP, yield, plant establishment, and fibre quality) were analysed by the ANOVA procedure at a level of significance of $p<0.05$ using Genstat 16 software [19].

\section{Results and Discussion}

The preliminary results of this SBPM study indicate that there was no statistically significant difference between the SBPM_gap treatment and ODP or CON for almost all the tested parameters. However, with respect to water consumption and crop water productivity, the plot with the SBPM_gap had a tendency for higher crop water productivity $(+12 \%$ and $+8 \%)$ compared to the ODP film treatment and CON (Table 1). Cotton grown on the SBPM_gap treatment plot used 13 and $23 \mathrm{~mm}$ less water and produced 0.4 and $0.6 \mathrm{~kg} \mathrm{~mm}^{-1} \mathrm{ha}^{-1}$ more lint compared with the CON and ODP film, 
respectively; a similar result to that achieved was reported in other studies using thin polyethylene (PE) film [20]. Using the same SBPM product, researchers reported a reduced soil evaporation rate of $10 \%-50 \%$ (in pot experiments) and a larger crop productivity (in rockmelons) of up to $30 \%$ [13]. Plant establishment (51 days) was within the target range of 8-12 plants $\mathrm{m}^{-1}$, with a significantly lower establishment on the CON (Table 2). This might be the result of slightly elevated soil temperature in treated plots compared to the no mulch plot at the initial growing stages (e.g., up to 51 DAS; Figure 2). In this study, we did not find significant differences among the treatments in lint yield or fibre quality (Table 2). However, the lint yield was higher by 5\%-7\% in the SBPM_gap treatment, showing that this new product may have potential benefits for cotton yield. Similar novel polymeric protein-based biocomposites applied using the spray technique resulted in adequate agronomic performance (plant growth and dry matter content) [10].

Table 1. The comparison of crop water consumption and crop water productivity of cotton grown on plots treated with sprayable biodegradable polymer membrane (SBPM), oxo-degradable plastic (ODP) mulch film, and a control plot with no mulch (CON) during the 2015/16 season at the ACRI field site ( $n=9$ plots $)$.

\begin{tabular}{|c|c|c|}
\hline Treatment & Crop Water Consumption (mm) & Crop Water Productivity $\left(\mathrm{kg} \mathrm{ha}^{-1} \mathrm{~mm}^{-1}\right)$ \\
\hline $\mathrm{CON}$ & $667^{\mathrm{a}}$ & $5.1^{\mathrm{a}}$ \\
\hline ODP film & $677^{\mathrm{a}}$ & $4.9^{\mathrm{a}}$ \\
\hline SBPM_gap & $654^{\mathrm{a}}$ & $5.5^{\mathrm{a}}$ \\
\hline
\end{tabular}

Means with the same letter are not significantly different at $p<0.05$.

Table 2. The comparison of final cotton establishment in 2015/16 (51 DAS), plant height (122 DAS), lint yield and fibre quality ${ }^{1}$ parameters of cotton grown on plots treated with sprayable biodegradable polymer membrane (SBPM), oxo-degradable plastic (ODP) mulch film, and a control plot with no mulch (CON) at the ACRI field site ( $n=9$ plots).

\begin{tabular}{|c|c|c|c|c|c|c|}
\hline Treatment & $\begin{array}{l}\text { Establishment } \\
\text { (plants } \mathrm{m}^{-1} \text { ) }\end{array}$ & $\begin{array}{l}\text { Height } \\
\text { (cm) }\end{array}$ & $\begin{array}{c}\text { Lint yield } \\
\left(\mathrm{kg} \mathrm{ha}^{-1}\right)\end{array}$ & $\begin{array}{l}\text { Fibre Strength } \\
\left(\mathrm{g} \mathrm{tex}^{-1}\right)\end{array}$ & $\begin{array}{l}\text { Fibre Length } \\
\text { (dec. inch) }\end{array}$ & $\begin{array}{c}\text { Micronaire } \\
(-)\end{array}$ \\
\hline $\mathrm{CON}$ & $7.8^{b}$ & $98.1^{a}$ & $2884^{a}$ & $27.8^{a}$ & $1.16^{\mathrm{a}}$ & $4.69^{a}$ \\
\hline ODP film & $10.2^{\mathrm{a}}$ & $100.0^{\mathrm{a}}$ & $2839^{a}$ & $26.8^{a}$ & $1.18^{\mathrm{a}}$ & $4.69^{a}$ \\
\hline SBPM_gap & $10.3^{a}$ & $97.2^{a}$ & $3032^{a}$ & $26.9^{a}$ & $1.18^{\mathrm{a}}$ & $4.69^{a}$ \\
\hline
\end{tabular}

Means with the same letter are not significantly different at $p<0.05 .{ }^{1}$ Fibre quality parameter base grades: Strength $>29 \mathrm{~g} \mathrm{tex}^{-1}$, Length $>1.125 \mathrm{dec}$. inch., Miconaire 3.8-4.5.

For the seedbed temperature measurements (at $10 \mathrm{~cm}$ ), an additional plot with spray-on SBPM applied over the plant line (SBPM_full) was also included. Seedbed temperatures were slightly elevated under the ODP film and SBPM early in the season, a similar response to that observed in previous studies using thin plastic mulch film, which enables earlier planting or planting in cooler regions in Australia [21]. The SBPM_gap increased soil temperature compared to the control, but only between 21 and 38 days. It was observed that the soil temperature was lower in the treatments that took place later in the season, which was probably the result of increased soil moisture during the treatments. Similar results have been reported for cotton grown under PE film when compared with planting on non-mulched soil [6]. These studies used either non-degradable plastic or oxo-degradable plastic films which, contrary to the SBPM technology, could pose a threat to the environment in terms of the retrieval of the plastic film and soil and water pollution [22]. This preliminary study looked at the potential to incorporate SBPM technology into the existing Australian cotton (and similar) production systems where cotton is mechanically planted on raised beds and irrigated with flood-furrow irrigation. Implementing SBPM to conserve soil moisture may improve crop water productivity, with the ease of spray application and no environmental pollution or disposal costs [11,12]. The SBPM_gap treatment showed that it may have the potential to improve CWP, but the application rate and coverage width still need to be optimized to minimize production costs, while enhancing growing benefits. Research 
is ongoing to achieve this result. As the plant line had to be left uncovered for the seeds to emerge, the SBPM_gap application technique probably limited the full agronomic potential of SBPM cover.

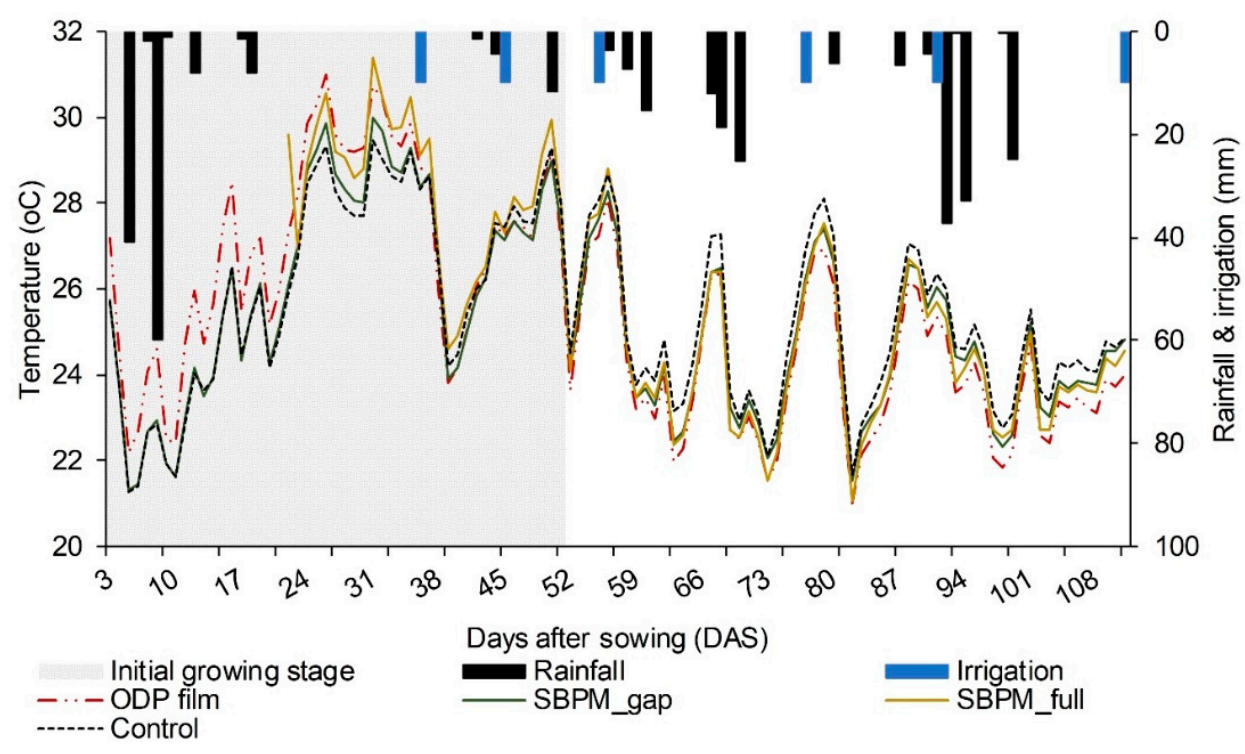

Figure 2. The effects of oxo-degradable plastic (ODP) mulch film and sprayable biodegradable polymer membrane (SBPM_gap and SBPM_full) treatments on soil temperature $\left({ }^{\circ} \mathrm{C}\right)$ measured at $10 \mathrm{~cm}$ soil depth, during 2015/16 at the ACRI field site ( $n=10$ plots; SBPM_full not replicated).

Additionally, it was noted that in the (non-replicated) SBPM_full treatment, where the SBPM covered the plant line, the soil profile remained wetter $(15-20 \mathrm{~mm}$ ) throughout the season (Figure 3). This result is highlighted in Figure 3b, where water content in the soil profile under the SBPM_full treatment was wetter than the control plot. It is important to note that the soil water content in the SBPM_full treatment was higher from the start of the experiment, which also may indicate different soil hydraulic properties (water retention capacity) or different initial soil water status. However, both SBPM treatments (_gap and _full) indicated higher moisture content at various soil depths (not shown) and during multiple measurements taken throughout the growing season, which was probably associated with the presence of the SBPM layer at the soil-atmosphere interface (which limited soil evaporation). It was also evident that the gaps above the plant line in the slotted ODP film contributed to water loss from the soil. Both the slotted film and SBPM treatments did not impede infiltration of rainfall or irrigation water, which suggests that the technology could be used to harvest water under rain-fed conditions in a similar manner to the plastic mulch [23]. Previous research on using thin plastic mulch film in cotton was largely focussed on developing agricultural farming systems to extend cotton production to drier regions where mulch is used to harvest and conserve meagre rainfall and water under drip or saline water irrigation [6,24]. Four types of biodegradable plastic were tested as alternatives to polyethylene mulch and they all showed similar influence on soil temperature and water content, indicating that biodegradable products present viable replacement options [8]. However, this information should be treated with caution, as some authors [3] have raised concerns due to possible micro- and nano particle residues in the soil. The new SBPM technology was declared to be completely in line with the strict biodegradability and nontoxicity standards [12,13]. However, it needs to be stressed that the expectations of creating a biodegradable product which has similar properties and as low production costs as plastic mulch may be somewhat challenging (at least in its initial development phase). Nevertheless, significant improvements are currently being made with SBPMs and similar technologies in order to overcome these and any other issues [25]. 

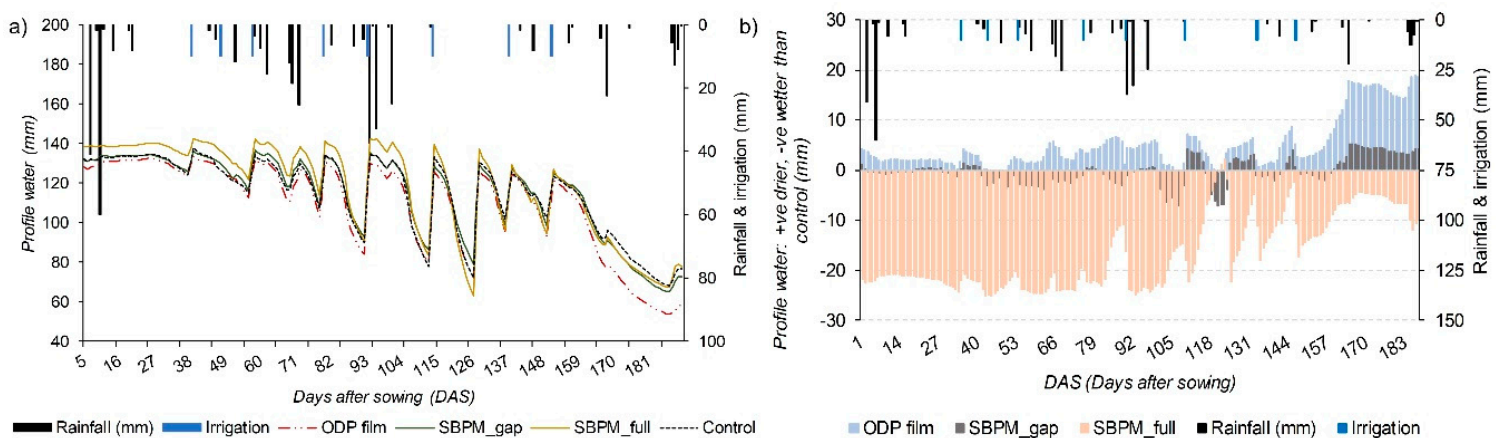

Figure 3. (a) The effect of oxo-degradable plastic (ODP) mulch film and sprayable biodegradable polymer membrane (SBPM_gap and SBPM_full) treatments on cumulative soil profile water content (mm) during the cotton growing season 2015/2016 at the ACRI field site ( $n=10$ plots; SBPM_full not replicated); (b) the comparison of soil profile water under the ODP, SBPM_gap and SBPM_full treatments, shown in relation to the control: positive is drier and negative is wetter than the control.

\section{Conclusions}

This preliminary field study shows that a novel sprayable biodegradable polymer membrane (SBPM) technology has the potential to replace preformed slotted oxo-degradable plastic (ODP) mulch films by providing a similar performance in terms of yield, crop water productivity (CWP), and soil temperature. The field testing of the new SBPM technology was limited by the availability of the product, which is still under development. A small-scale field-testing phase was undertaken to validate the agronomic performance of the new technology in order to move on to a larger-scale experimental trial. Nonetheless, results highlighted a tendency to achieve higher CWP and crop yield, increased soil temperature at the initial cotton growing stage, and increased soil water content with the SBPM cover. New large-scale field trials should focus on the application of improved SBPM formulations and their management. The SBPM technology is a promising solution with which to replace the vast amount of plastics that originate from crop production, due to its agronomic performance in comparison with plastic mulch films, simplicity of application and biodegradability into non-toxic compounds.

Author Contributions: Conceptualization, M.V.B. and P.S.C.; methodology, M.V.B., P.J., K.L.B.; software, M.V.B.; formal analysis, R.A., G.F., L.F., Y.W., V.F.; investigation, M.V.B., K.L.B.; writing—original draft preparation, M.V.B., R.A., G.F., P.J., P.S.C.; writing-review and editing, V.F. and L.F.; visualization, V.F. and Y.W. All authors have read and agreed to the published version of the manuscript.

Funding: This research was funded by CSIRO, while UKF/CSF agencies (grant number No. 3/19), Croatia, provided travel funding for Dr. Vilim Filipović and Dr. Lana Filipović.

Acknowledgments: The authors acknowledge Darin Hodgson and Shanna Smith for assisting in the establishment of the field experiment and CSIRO for funding the field experiment. The UKF visiting grant (assigned to Vilim Filipović) for bilateral research project EnviroSBPM (https://sites.google.com/view/envirosbpm/) between the University of Zagreb Faculty of Agriculture, Croatia and CSIRO Agriculture \& Food is acknowledged as well. We acknowledge support by the Open Access Publication Fund, University of Zagreb Faculty of Agriculture.

Conflicts of Interest: The authors declare no conflict of interest.

\section{References}

1. Alexandratos, N.; Bruinsma, J. World Agriculture towards 2030/2050: The 2012 Revision; ESA Working paper No. 12-03; FAO: Rome, Italy, 2012.

2. Jabran, K.; Ullah, E.; Hussain, M.; Farooq, M.; Zaman, U.; Yaseen, M.; Chauhan, B.S. Mulching improves water productivity, yield and quality of fine rice under water-saving rice production systems. J. Agron. Crop. Sci. 2014, 201, 389-400. [CrossRef]

3. Sintim, H.Y.; Flury, M. Is biodegradable plastic mulch the solution to agriculture's plastic problem? Environ. Sci. Technol. 2017, 51, 1068-1069. [CrossRef] [PubMed] 
4. Shogren, R.L. Biodegradable mulches from renewable resources. J. Sustain. Agric. 2000, 16, 33-47. [CrossRef]

5. Chen, N.; Li, X.; Šimůnek, J.; Shi, H.; Ding, Z.; Peng, Z. Evaluating the effects of biodegradable film mulching on soil water dynamics in a drip-irrigated field. Agric. Water Manag. 2019, 226, 105788. [CrossRef]

6. Dai, J.; Dong, H. Intensive cotton farming technologies in China: Achievements, challenges and counter measures. Field Crop. Res. 2014, 155, 99-110. [CrossRef]

7. European Bioplastics e.V. EUBP. EU Takes Action Against Oxo-Degradable Plastics. Available online: https://www.european-bioplastics.org/eu-takes-action-against-oxo-degradable-plastics/ (accessed on 17 May 2019).

8. Sintim, H.Y.; Bandopadhyay, S.; English, M.E.; Bary, A.I.; DeBruyn, J.M.; Schaeffer, S.M.; Miles, C.A.; Reganold, J.P.; Flury, M. Impacts of biodegradable plastic mulches on soil health. Agric. Ecosyst. Environ. 2019, 273, 36-49. [CrossRef]

9. Vaicekauskaite, J.; Ostrauskaite, J.; Treinyte, J.; Grazuleviciene, V.; Bridziuviene, D.; Rainosalo, E. Biodegradable linseed oil-based cross-linked polymer composites filled with industrial waste materials for mulching coatings. J. Polym. Environ. 2019, 27, 395-404. [CrossRef]

10. Sartore, L.; Schettini, E.; Palma, L.; Brunetti, G.; Cocozza, C.; Vox, G. Effect of hydrolyzed protein-based mulching coatings on the soil properties and productivity in a tunnel greenhouse crop system. Sci. Total. Environ. 2018, 645, 1221-1229. [CrossRef] [PubMed]

11. Adhikari, R.; Bristow, K.L.; Hornbuckle, J.; Freischmidt, G.; Casey, P. Novel sprayable biodegradable polymer membrane to minimize soil evaporation. In Proceedings of the International Conference on Technologies for Sustainable Development (ICTSD 2015), Mumbai, India, 4-6 February 2015; pp. 1-4.

12. Adhikari, R.; Casey, P.; Bristow, K.L.; Hornbuckle, J.; Freischmidt, G. Sprayable Polymer Membrane for Agriculture. U.S. Patent WO/2015/184490, 10 December 2015.

13. Adhikari, R.; Bristow, K.L.; Casey, P.S.; Freischmidt, G.; Hornbuckle, J.W.; Adhikari, B. Preformed and sprayable polymeric mulch film to improve agricultural crop water productivity. Agric. Water Manag. 2016, 169, 1-13. [CrossRef]

14. Adhikari, R.; Mingtarja, H.; Freischmidt, G.; Bristow, K.L.; Casey, P.S.; Johnston, P.; Sangwan, P. Effect of viscosity modifiers on soil wicking and physico-mechanical properties of a polyurethane based sprayable biodegradable polymer membrane. Agric. Water Manag. 2019, 222, 346-353. [CrossRef]

15. Braunack, M.V.; Zaja, A.; Tam, K.; Filipović, L.; Filipović, V.; Wang, Y.; Bristow, K.L. A Sprayable Biodegradable Polymer Membrane (SBPM) technology: Effect of band width and application rate on water conservation and seedling emergence. Agric. Water Manag. 2020, 230, 105900. [CrossRef]

16. Hulugalle, N.R.; Weaver, T.B.; Finlay, L.A.; Lonergan, P. Soil properties, black root-rot incidence, yield and greenhouse gas emissions in irrigated cotton cropping systems sown in a Vertosol with subsoil sodicity. Soil Res. 2012, 50, 278-292. [CrossRef]

17. French, R.; Schultz, J. Crop water productivity of wheat in a Mediterranean-type environment. I. The relation between yield, water use and climate. Aust. J. Agric. Res. 1984, 35, 743-764. [CrossRef]

18. Holzworth, D.P.; Huth, N.I.; deVoil, P.G.; Zurcher, E.J.; Herrmann, N.I.; McLean, G.; Chenu, K.; van Oosterom, E.J.; Snow, V.; Murphy, C.; et al. APSIM-Evolution towards a new generation of agricultural systems simulation. Environ. Modell. Softw. 2014, 62, 327-350. [CrossRef]

19. VSN International. Genstat for Windows 18th Edition; VSN International: Hemel Hempstead, UK, 2015.

20. Zhang, S.; Sadras, V.; Chen, X.; Zhang, F. Crop water productivity of dryland wheat in the Loess Plateau in response to soil and crop management. Field Crop. Res. 2013, 151, 9-18. [CrossRef]

21. Braunack, M.V.; Johnston, D.B.; Price, J.; Gauthier, E. Soil temperature and soil water potential under thin oxodegradable plastic film impact on cotton crop establishment and yield. Field Crop. Res. 2015, 184, 91-103. [CrossRef]

22. Chen, Y.; Wu, C.; Zhang, H.; Lin, Q.; Hong, Y.; Lou, Y. Empirical estimation of pollution and contamination levels of phthalate esters in agricultural soils from plastic film mulching in China. Environ. Earth Sci. 2013, 70, 239-247. [CrossRef]

23. Bu, L.; Liu, J.; Zhu, L.; Lou, S.; Chen, X.; Li, S.; Hill, R.L.; Zhao, Y. The effects of mulching on maize growth, yield and water use in a semi-arid region. Agric. Water Manag. 2013, 123, 71-78. [CrossRef] 
24. Dong, H.; Li, W.; Tang, W.; Zhang, D. Early plastic mulching increases stand establishment and lint yield of cotton in saline fields. Field Crop. Res. 2009, 111, 269-275. [CrossRef]

25. Filipović, V.; Bristow, K.L.; Filipović, L.; Wang, Y.; Sintim, H.Y.; Flury, M.; Šimůnek, J. Sprayable biodegradable polymer membrane technology for cropping systems: Challenges and opportunities. Environ. Sci. Technol. 2020. [CrossRef]

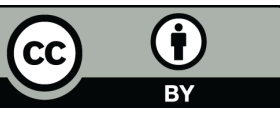

(C) 2020 by the authors. Licensee MDPI, Basel, Switzerland. This article is an open access article distributed under the terms and conditions of the Creative Commons Attribution (CC BY) license (http://creativecommons.org/licenses/by/4.0/). 